\title{
Cinderella Syndrome of Working Women Characters in Cyber Literature
}

\author{
${ }^{1}$ Eva Fatimah and ${ }^{2}$ Imas Istiani \\ ${ }^{1}$ Universitas Wahid Hasyim, Semarang \\ ${ }^{2}$ Universitas Negeri Semarang, Semarang \\ Email (eva@unwahas.ac.id)
}

Article History: January $7^{\text {th }}, 2021$; Accepted January $28^{\text {th }}, 2021$; Published January $30^{\text {th }}, 2021$

\begin{abstract}
Cyber literature has been academically recognized in literary studies through multiple research studies. Cyber literature is manifested in various cyberspace, both maintained individually and professionally. Writing platforms on the internet, such as Wattpad, have been widely used. They provide space for writers and engage readers to create online writing communities. One of the most popular genres found in cyber literature is romance chick-lit, in which most main characters are working women. Although most protagonists are working women who are financially independent, they still search for men who have higher positions, social levels, and financial stability. They wish that such men will find and save them, referred to by Colette Dowling as Cinderella complex. The study investigates the Cinderella complex's indications on female protagonists in two Wattpad chick lit works: 1) Furious Boss \& Naughty Secretary, and 2) Ex-lovers but Married. The indications of Cinderella Complex were shown through 1) the wish to be saved, 2) the girlchild lives on, 3) the achievement gap, 4) the intimations of helplessness, and 5) the blind devotion.
\end{abstract}

Keywords: Cinderella complex; cyber literature, Wattpad

\begin{abstract}
Abstrak. Sastra cyber sudah diperhitungkan sebagai bagian dari studi sastra secara akademik melalui berbagai penelitian yang sudah dilakukan. Sastra cyber terwujud di dalam berbagai ruang cyber, baik itu dijalankan secara individual maupun profesional. Platform menulis pada internet seperti Wattpad sudah marak digunakan sebagai tempat berkarya bagi penulis serta menarik perhatian pembaca untuk menciptkana suatu komunitas menulis secara online. Salah satu genre populer pada sastra cyber adalah chicklit romantis yang mana karakter utamanya adalah wanita pekerja. Meskipun protagonis wanita merupakan wanita pekerja yang independen secara finansial, mereka masih mengharapkan pasangan yang berada di posisi, tingkat sosial dan kestabilan finansial yang lebih besar dari mereka. Studi ini bertujuan untuk mencari indikasi adanya Cinderella complex pada karakter protagonis perempuan melalui dua karya chicklit di Wattpad, yaitu: 1) Furious Boss \& Naughty Secretary, dan 2) Mantan Tapi Menikah. Indikasi Cinderella complex yang ditemukan adalah 1) keinginan untuk diselamatkan, 2) gadis-kecil yang hidup di dalam diri, 3) kesenjangan prestasi, 4) tanda ketidakmampuan, dan 5) kepatuhan yang buta.
\end{abstract}

Kata kunci: Cinderella complex; sastra cyber, Wattpad

\section{INTRODUCTION}

Due to the vast development of Information and Communication Technology (ICT) along with the unavoidable need for the internet, cyberspace has been dispersed and immersed into human life and transformed into various forms of functions and uses. The fusion of 
ICT and the internet also influences the literary world. Literature is not only a creative work printed on papers by a publishing company; it can also be on the computer screen connected to the internet, known as cyber literature. It was initially performed individually in social media or individual blogs. However, nowadays, many platforms have provided online writing communities, such as Commaful, Wattpad, fanfiction.net, Tumblr, WritersCafe, The Young Writers Society, and many more. These platforms allow for cyber literature to develop more professionally. Writers can monetize the works that prompt them to write what their potential readers want to read.

One of the distinctive characteristics of cyber literature is the massive interaction between the authors and the readers. Unlike conventional literary work, where authors and readers are hardly engaged in interactive communication, cyber literature erases the border between two parties. This fast and massive interaction can yield to the forms and the contents of the creative works. Some works posted in the online writing communities are not finished yet, or on-going. The authors expect comments, ideas, opinions, and suggestions from their readers that eventually shape the development and the ending of the works.

Most of the creative works in online writing communities are categorized as popular literature. It refers to a group of genres that is widely consumed by the current society. Teen literature (teen lit) and chic literature (chick lit) are two prominent genres of popular literature that are also easily found in many online writing communities. The rising of the two genres is considered as the teenagers' movement with the power of media in the creative industry (Agustina, 2017). Both genres are well received by the young readers mainly because they narrate the characters' love relationship. However, the settings are likely to be different; teen lit is usually located in schools, whereas chick-lit is in workplaces.

Romance and love are the most widely written topics that can seep into many other forms and genres, from folktales into gothic. In chick-lit, typically, the main characters are working women who fall in love with their colleagues, who happen to be their bosses, supervisors, and even the companies' owners. This mainstream love story is basically like Cinderella, where a woman who has nothing marries a man who has everything. This phenomenon creates the Cinderella complex where women wish their princess to come and save them from life's misery. The relationship between the Cinderella Complex with teenlit was noted by Intan (2019) in her paper. She revealed the forms of the Cinderella Complex found in 2) the female characters' dependency on the male characters and 3) the spoiled and weak characters attributed as feminine characters.

Thus, it is intriguing to see the typical romance plots of chick-lit found in online writing communities as a part of cyber literature. This research aimed at revealing how the Cinderella complex was manifested in chick-lit through plots and characters found in cyber literature. The objects of the study are two complete fictional works in Wattpad, as one of the most prominent online writing platforms to this date. The creative works were chosen based on popularity, numbers of viewers, completion, working female characters, and female authors' creation.

\section{Cyber Literature}

Cyber literature has been a part of modern society's cultural domain since the development of information and technology. It was predicted that cyber literature was formed in 1990 
and gained popularity in 1998 (Septriani, 2016). It was started from general sites, mailing lists, forums, and personal blogs where they were maintained individually. Cyber literature can easily be found along with the vast social media movement, either as users' posts or responses. Online writing platforms then create cyberspace for amateur authors and potential readers to write, create, share, and appreciate the creative works.

Cyber literature is any work of literature created and presented using computers as the media (Viires, 2005). Further, Viires sets out three categorizations under the umbrella of cyber literature; they are:

1. any literary texts presented on the Internet from the professional authors, whether the authors post the works themselves (in their websites), or printed literary texts that are documented and digitalized by the third parties (in professional websites),

2. any literary texts posted by amateur writers who find the Internet (personal blogs, social media, online writing platforms, writing groups) as accommodating places to publish their works so more people can read them, and

3. hypertext literature and cybertexts that are signified by computer and technology development, creating multilinearity among texts, multimedia, and interactivity between texts and readers.

Cyber literature also has other similar terms such as "digital literary" (Hoover et al. 2014) and "electronic literature" (Hayles, 2008; Zalbidea and Sotelo, 2014). Unlike Viires, Hayles (2001) does not consider the digitized print literature as a part of electronic literature. She claims that electronic literature is "digital-born" and is intended to be composed, shared, and read on a computer. Hayles points out that the fundamental difference between electronic literature from print literature is "it [electronic literature] cannot be accessed until it is performed by properly executed code." Nugraha \& Suyitno (2020) assert that electronic literature is not just a different medium between cyber literature and traditional literature; electronic literature is intended to be enjoyed and read on a computer screen. It can lose its aesthetical feature if it is printed.

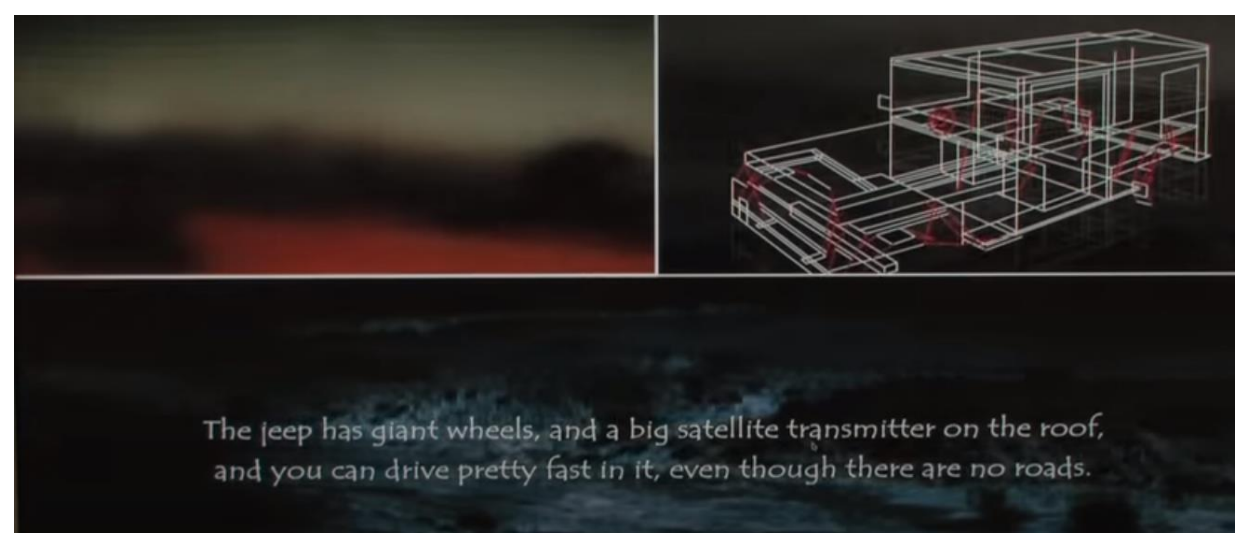

Figure 1 The Example of Electronic Literature

As seen in Figure 1, electronic literature contains text, moving pictures, and audio. Some works of electronic literature even allow readers to choose how the story goes. 
While print literature can be accessed anytime as long as readers have books, electronic literature requires special access. Thus, the appreciation of electronic literature comes from the fuse of literary and technical production. Hayles then classifies the genres of electronic literature into 15 categories; they are (1) hypertext fiction; (2) interactive fiction; (3) hypertext poetry; (4) interactive poetry; (5) animated poetry; (6) email-or blog-based fiction; (7) computer installed literature; (8) computer-generated fiction; (9) computergenerated poetry; (10) collaborative fiction; and (11) online fiction (Merawati and Suwartini, 2019).

Fizek (2007) perceives cyber literature as a "radical metamorphosis" against the traditional literature that no longer depends on texts but involves other media forms from graphics, pictures, audio, videos, and animations. Although digital mediums are attached to the texts as the integral parts, Fizek claims that the hyperliterature analysis should use the same traditional narrative exploration. Thus, when discussing cyber literature, we should consider both the technological aspects and the narrative aspects.

Many aspects can be used to analyze and discuss the influence of technology on cyber literature. Merawati and Suwartini (2019) gather and classify topics on cyber literature in Indonesia. They find that some topics are in the continuity (such as the authors' position, definitions and genres of cyber literature, and readers' position). On the contrary, the discontinuity is vividly shown by the reluctance of making cyber literature into a canon. Thus, rejection prevents cyber literature from growing and developing, which can enrich Indonesia's literary field.

Merawati and Suwartini argue that one of the most commonly discussed topics in cyber literature arises from readers' responses to the texts. Rahman (2017) surveys to gather readers' opinion on cyber literature found in social media. He finds that respondents give more positive replies to the existence of cyber literature. He claims that cyber literature can arouse readers' appreciation of literature in cyberspace through reactions and comments.

Like Rahman's study focused on respondents' opinion, Yoesoef (2019) examines how generation $\mathrm{Z}$ reads cyber literature through two online writing platforms: Wattpad and Webnovel. Readers of Generation $Z$ are not bound to any labels like "bestsellers," "winner of the competition," etc. The readers have total freedom to choose any literary genre, usually under the classification of popular literature. Amateur writers in Wattpad and Webnovel are open to creativity and innovation so that their works can be popular. Once work is famous, there is a big chance to be published by professional publishing companies, and even can be turned into a widescreen movie.

\section{Wattpad}

Wattpad is one of the biggest platforms of the online writing community to this day. Many studies on cyber literature used Wattpad as their medium due to its significant influence on readers across ages and countries. Readers feel that Wattpad has substantial impacts on their life. Once they get engaged in reading on Wattpad, they are addicted to it. Contreras et al. (2015) investigate the readers' engagement to Wattpad. The triggering factors are "surrounding people," "interest in literature," "social media," "boredom," "free cost," and "convenience." Meanwhile, the factors that maintain the readers' interest come from "learning satisfaction" and "emotional satisfaction." 
Not only engaging the readers, but Wattpad has also been successful in maintaining the authors' interest. Several features help authors know the numbers of readers, comments, followers, and votes on their works. Those features lead to the authors' popularity that can trigger them to be more productive and creative. The popularity also motivates the authors to be more professional so that their works can be profitable. Many famous works have been published in print, either by indie or professional publishing companies. Most Wattpad authors choose to publish their results with indie publishers to reach more than 500 authors (Mawardi, 2018).

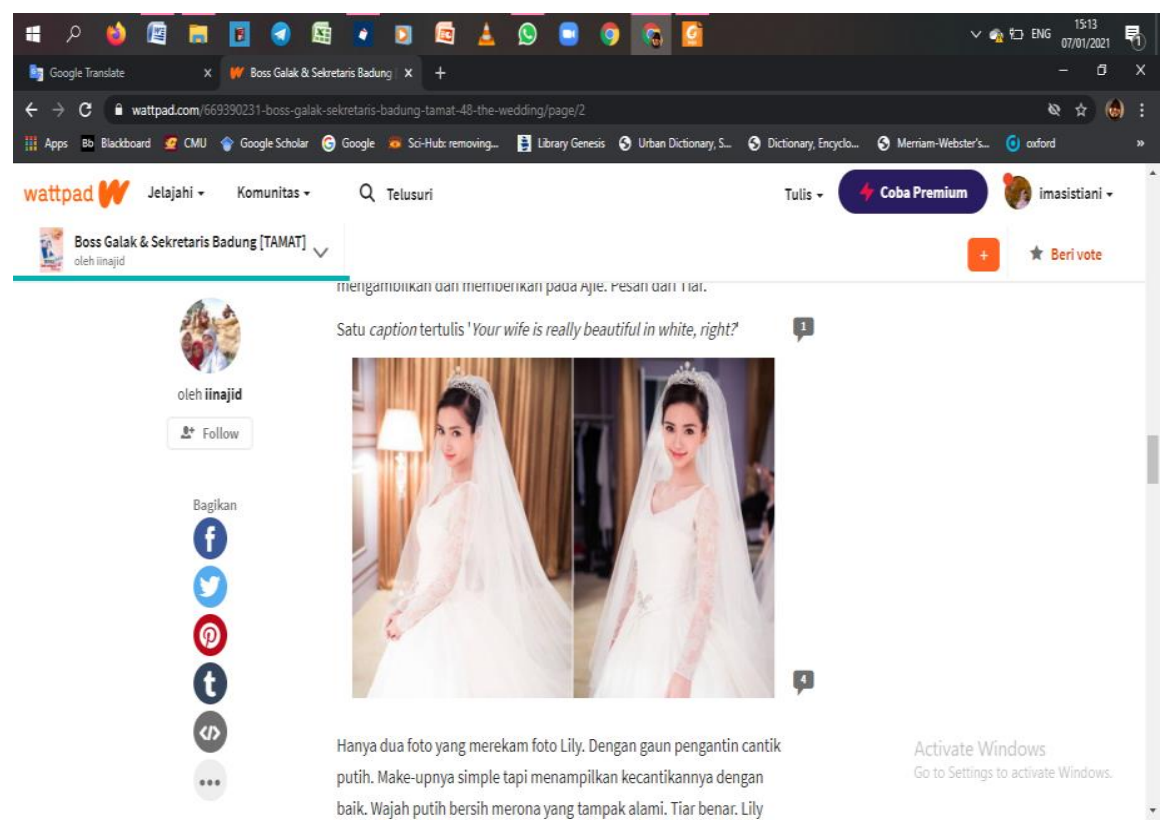

Figure 2 The Example of Wattpad Stories

The figure above is taken from one of the chapters in Furious Boss \& Naughty Secretary (FBNS). The chapter has several pictures to visualize the scenes; one of them is the wedding party. The main character, Lily, was narrated as wearing a white wedding dress that emphasized her beauty. Readers made some comments at any line or pictures, showing their opinions on the texts or pictures. Putting pictures on the story connect authors and readers that create engagements among them.

Wattpad authors' existences rely heavily on the popularity of their works. To attract as many readers as possible, they employ two kinds of strategies. First, they make use of available features on the platform to strengthen the contents of the story. They insert audios, pictures, animations, and even videos that help readers visualize the stories and catch the readers' attention. Second, authors write the genre that most readers are interested in; romance. As a result, most stories have similar plots and characterizations that are easy to guess. Mawardi (2020) compares the similarity in style between Wattpad stories and popular literature (chick lit and teen lit) that were flourished in 2000.

\section{Cinderella complex}

Cinderella complex was first coined by Colette Dowling, a New York psychotherapist who was famous for treating women's problems. Dowling (1981) realized that women possessed the tendency and dependency to be taken care of by others, especially men. Just like Cinderella, women wait for external forces to make their life better and their futures 
brighter. They don't rely on themselves; they need others to create magic. They don't believe that they can create their happiness since "the charming prince" is out there, searching for them.

Colette Dowling admitted that the realization of the Cinderella complex's existence was, ironically, evoked by men. After divorce, Dowling had managed her household along for years with three young children to feed by writing professionally. When she met another man, Lowell, who agreed to move in with her, Dowling suddenly could not support the family anymore. She was too convenient with the domestic role and let Lowell be the provider of the family. Dowling admitted that doing "shit-jobs" and "housewifery" required "less anxiety-provoking than being out there in the adult world fending for oneself." After months of living as "traditional helper, putterer, amanuensis, typist of someone else's dreams," Dowling realized she was afraid of being independent and having to take care of herself. She wanted someone to "save her" from the need to pay the bills, from seeing the landlord, from providing food on the table. The "wish to be saved" is then called the Cinderella complex. This syndrome can weaken one's dream, reduce one's ambition, and change one's independence into dependency.

After women gained more empowerment and support to be independent in the 90s, the concept stirred perplexity and irritation among women (Saha and Safri, 2016). They did a small experiment by gathering 100-140 Indian women of various ages and statuses. After receiving an explanation about the Cinderella complex, the participants started realizing the Cinderella complex's effect on their lives. The housewives confirmed the syndrome that had been sipped into their minds. The working women realized that they were related to the syndrome. Single women acknowledged that they grew with the thought to be a good wife. No matter what statuses and ages women are, the Cinderella Complex scare women to be independent. It can cripple women's independence, cut their freedom, impede their dream, and obscure their ambition.

Chick-lit and teen-lit have distinctive themes and narrative styles that signify them as an integral part of popular literature (Intan, 2019). She reveals the Cinderella complex internalized in the female protagonists of two teen lit novels: Eiffel I'm in Love and Fairish. She finds that the Cinderella complex is triggered by immature personalities, authoritarian parenting styles, and low self-concept. The forms of the Cinderella complex are 1) the dependency on male characters and 2) the maintenance of spoiled and weak behaviors, which is considered feminine traits.

Cinderella complex is not only investigated for literary purposes, but also in real life. Hapsari et al. (2019) propose that all-female, both working and non-working, tend to depend on others, especially men. However, based on the study they conducted, they find that non-working women possess higher Cinderella complex scores. Cinderella complex forms are: wishing for male presence, the need to be protected, doing meaningless activities, the belief in outside assistance, fear of independence without others' assistance, being submissive to men.

\section{METHODS}

The intrinsic elements were explored to describe the plots, characters, and characterization found in the samples of the stories in Wattpad. The samples were chosen through these steps, 1) they were listed because of the popularity under the chick-lit genre, 2) the number 
of readers was more than 3 million views, 3) the novels were already completed, 4) the female protagonists were working women, and 5) the authors were female. Among the considerable number of the populations, the study only focused on the two novels; they were 1) Furious Boss \& Naughty Secretary (FBNS), and 2) Ex-lovers but Married (EBM).

Table 1 The Details of FBNS and EBM

\begin{tabular}{llllclll}
\hline No & Title & Eps & Read & Votes & Authors & $\begin{array}{l}\text { Female } \\
\text { Characters }\end{array}$ & $\begin{array}{l}\text { Male } \\
\text { Characters }\end{array}$ \\
\hline 1 & $\begin{array}{l}\text { Furious Boss \& } \\
\text { Naughty }\end{array}$ & 56 & 6.5 & $413 \mathrm{k}$ & Ms. iinajid & $\begin{array}{l}\text { Lily, } \\
\text { secretary }\end{array}$ & $\begin{array}{l}\text { Ajie, the } \\
\text { boss }\end{array}$ \\
& $\begin{array}{l}\text { Secretary } \\
\text { (FBNS) }\end{array}$ & & & & & \\
2 & $\begin{array}{l}\text { Ex-lovers but } \\
\text { Married (EBM) }\end{array}$ & & $\begin{array}{l}\text { M } \\
\text { M }\end{array}$ & $233 \mathrm{k}$ & Nuruulnz & $\begin{array}{l}\text { Kinan, } \\
\text { businesswo } \\
\text { man }\end{array}$ & $\begin{array}{l}\text { Arsen, } \\
\text { CEO }\end{array}$ \\
\hline
\end{tabular}

Although both female protagonists were working women, FBNS's female main character was the male main character's subordinate. Meanwhile, EBM's female main character was a successful businesswoman who could have the same level of power as her male main character. The difference in power was intended deliberately to see if it yielded different results. This qualitative study used a narrative analysis method to identify the indications of the Cinderella Complex defined by Dowling in the main female characters who were working in different careers.

The steps in the data collection were (1) deciding which novels that would be used in the research, (2) reading the novels several times, (3) highlighting the texts that suit the theory, and (4) writing down the collected data. Meanwhile, the data analysis were conducted through the following steps, they were (1) identifying the collected data, (2) determining the data, (3) classifying them into the suitable indications of the Cinderella Complex, (4) analyzing the data, and (5) drawing the connection and the conclusion between the data and the indication.

\section{RESULTS AND DISCUSSION}

Before analyzing the works, the summaries of the stories would be presented. FBNS tells the love story between Lily, an employee, and Ajie, Lily's boss. Ajie hired Lily immediately when she applied for a job since he clearly remembered Lily from his past. He told Lily that she had rejected him twice in the past, while Lily couldn't remember at all about the rejection. Once Lily was accepted as Ajie's secretary, Ajie kept Lily by his side to make her fall in love. Despite Ajie's cold personality, he kept his promise to Lily when they were little that they would get married. Eventually, Lily remembered how they met for the first time that caused Lily's phobia. In the end, Ajie and Lily got married.

EBM was a love story between Kinan and Arsen, who had previously dated but broke up because Arsen did not tell Kinan. Kinan owned a big restaurant that she built herself from the beginning. Meanwhile, Arsen was CEO of a company. One day, their parents insisted on an arranged marriage without knowing that Kinan and Arsen were ex-lovers. Obeying their parents, Kinan and Arsen ended up getting married. At the beginning of their marriage, they were still reluctant to open up. When Arsen's reason for breaking up with 
Kinan was finally revealed, the wall between them was crumbled, and they had a happy marriage afterward.

To reveal the Cinderella Complex in the stories, especially in Lily and Kinan, the researchers formulated several indications from Dowling's book (1981). There have been ample indications to select, but the study only limit to five indications, they are: 1) the wish to be saved, 2) the girl-child lives on, 3) the achievement gap, 4) the intimations of helplessness, and 5) the blind devotion.

\section{The wish to be saved}

The first indication is "the wish to be saved" where females do not believe that they can save themselves from problems and challenges in life. They believe that external forces will eventually come and save them from life misery. Just like Cinderella, who waits for the prince to take her out of the torturing family while she has the chance to free herself long before meeting the prince, women tend to expect others to help them. They don't realize that they let their freedom go and be dependent once they rely on others.

Jaya didn't reply. He just patted Ajie's shoulder. He took a deep breath. "Lily has changed significantly after meeting you, Jie. If it happened earlier, she would be more hysterical... Sometimes... she could not do anything for days." (EBM)

Lily was a beautiful, attractive woman that caught people's attention. She was weak and vulnerable. People closed to her knew this. She was always surrounded by someone who protected her; her boss/lover Ajie, her cousin Jaya, her best friend Tiar, and her parents. Despite her easy-going personality, she was fragile inside. At her 23, she still suffered from her phobia caused by a childhood incident. Sometimes she had manic episodes when the phobia was triggered. Lily and her families just let the phobia untreated, hoping that her phobia was gone by itself. However, when Ajie appeared again in Lily's life, the phobia slowly faded away and disappeared for good afterward. When Lily was locked in the office toilet by her colleagues, Lily passed out and should be hospitalized. Ajie's presence soothed Lily that she no longer had any manic episodes.

Saving a woman is linked to loving her. This belief is also acknowledged by Lily when she was about to test Ajie's love for her. Before proposing to her, Ajie never said that he loved her. Thus, Tiar gave Lily an idea to call Ajie and scream on the phone without giving any explanation, as if something terrible was happening to her. Lily believed in Ajie's love when he searched for her, even canceling his business trip for her. Ajie's worry and trying to find her were considered as a sign of love. This part of the plot underlines what Dowling refers to as "wishing to be saved."

In EBM, Kinan was a successful businesswoman who owned a fancy dining restaurant she built from the beginning. Considering that Kinan was 26 and had settled with a stable career, her parents asked her to get married. But Kinan was in doubt since she did not put marriage in her list.

"What is it that makes you hesitate, Nan? Your age is suitable to get married, and your career is promising, what else are you waiting for? Do you want to be a spinster? (EBM)

They were afraid that Kinan would be too old to get married, referring that Kinan's friend had already had her own little family by 23 . Kinan, who was forced to obey their parents 
and was also afraid of being too old to get married, finally agreed to the arranged marriage that turned out to be with her ex-lover, Arsen. She escaped from her parents' obligation and societal judgment by marrying Arsen. Being a spinster is a negative stigma in society. A spinster is perceived as a failure since a woman should get married once they have the eligible age in law.

Another "wishing-to-be-saved" indication can arise from their dependency on others. The dependence usually occurs when women feel helpless, in pain, or worried about something. This indicator is seen in one of the most typical scenes in romance; a bridal hug. Lily once sprained her ankle when she fell. Ajie, without any doubt, took her in his arms to bring her to the hospital. So did Arsen. He took Kinan when she fell. Both female characters feel helpless when they were in pain. They relied on their male characters to heal their pain. This feeling then develops into a romantic feeling since both Kinan and Lily felt protected and felt safe when they were in their males' arms. They believed that their male partners were their saviors for life.

\section{The girl-child lives on}

The second indication is the childish feeling of women despite their being adult women. Lily showed her childlike behavior when she was about to marry Ajie.

"Aaargh, the wedding is only once in life, Mas. Some strange requests will not hurt anyone," said Lily, making an excuse. She begged Ajie for understanding. (FBNS)

For their wedding party, Lily requested seven flavors of ice-cream for the night reception's dessert and seven layers of pink wedding cake. She also searched for the glass shoes and prepared a pink tuxedo for Ajie. Ice cream, cake, glass shoes, and pink are all associated with girls. Lily wanted to make her wedding dream like a little girl imagines how a wedding should look. The indication of the Cinderella syndrome is strong when Lily wished to wear glass shoes for her wedding party.

Meanwhile, Kinan does not directly show her childish behavior. However, she was highly dependent on others for personal matters, not only to Arsen but also to her twin; Kiran, her friend; Ranti, her parents, and her mother-in-law. Kinan let Arsen choose her what to wear. Kinan let her family decide everything on her wedding, from preparation until the honeymoon. Kinan even asked for Ranti's suggestion on how to open up to her husband. They clearly showed that Kinan was highly dependent.

\section{Achievement gap}

The third indication is women's belief that their companion's achievement is more important than their own. Women always believe that "behind a great man, lies a great woman." This proverb has been sipped so powerfully into the society that women are willing to surrender for their men's achievement. In FBNS, Lily claims that she wants to be Ajie's secretary forever once they got married. Lily seems to forget her ambition to pursue her career. She could have asked Ajie to put her in a strategic position in his company. But Lily chose to stop thinking over her job and focus on her marriage.

\footnotetext{
"Hush... husband! Thank you for waiting for me this far. I feel sorry for it as well. I... I promise to be your wife, lover, best friend, and of course, your secretary forever.. Uhm, and also your Minister of Finance!" ( $\mathrm{FBNS}$ )
} 
Lily vowed on her wedding day to be Ajie's secretary forever. Although it could be intended as a joke, since her dream of marrying a handsome, rich guy came true, it also showed that Lily would cease pursuing her career in Ajie's company. By mentioning that she would become Ajie's "Minister of Finance," Lily was trapped in one of the traditional roles of a housewife, managing her husband's money.

The same indication is also found in EBM. Kinan, who owned a big restaurant, subdued her ambition once she married Arsen, as illustrated in the text below when Kinan talked with her twin, Kiran.

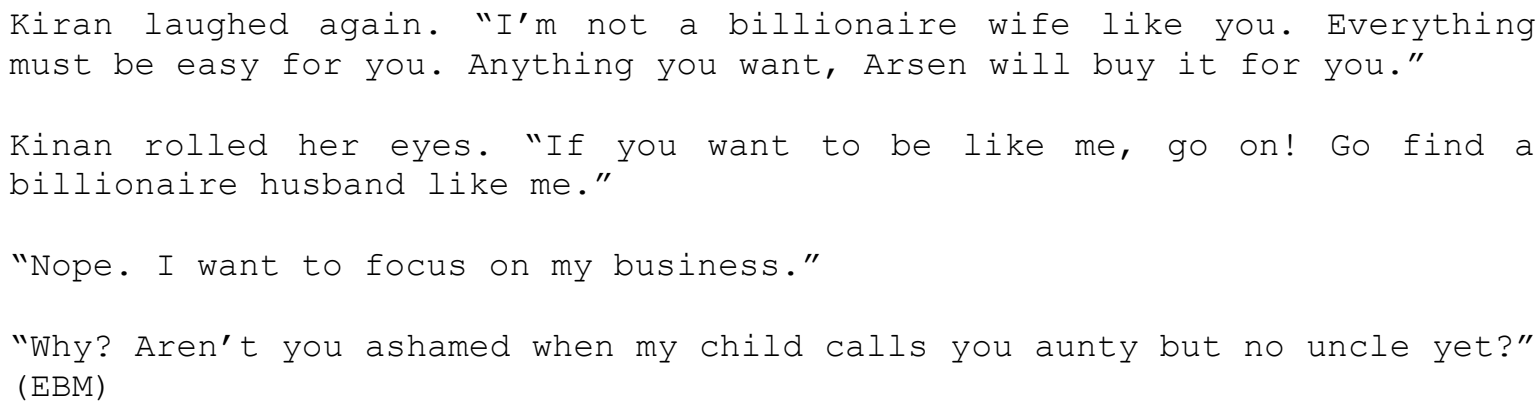

This phone conversation happened when Kiran just expanded her culinary business. Instead of congratulating Kiran on her business, Kinan teased her twin for being single after Kiran broke up with her cheating boyfriend. Kiran's persistence in developing her business by herself was not acknowledged as an "achievement." Instead, Kiran was teased and considered as failed due to her being single. Kinan, who owned a big restaurant, should have been proud of her achievement. After Kinan got married, she always referred to herself as "a billionaire wife," not "a successful chef."

\section{Intimations of helplessness}

The fourth indication is the helplessness shown by the female characters. This indication is depicted by FBNS when Lily felt helpless because of Ajie, her male partner.

There were many handsome men around Lily, but her brain just stopped dead. Working aimlessly. Like losing a focal point. Her boss influenced her so strong that Lily was confused. When Ajie was furious, she was afraid. When Ajie was dismayed, she was confused. When Ajie was silent, she got more worried. (FBNS)

Lily's helplessness seems reasonable due to the power relationship between herself and Ajie, her boss. However, the quotation above implies that Lily's helplessness is more than a professional relationship. It takes Lily personally and emotionally that everything Ajie does, Lily is confused.

Helplessness is not only intrigued due to the social gap between employee and employer, it is also found between the main characters who are equal in social status. Kinan and Arsen are equal in social status since both are described as having financial stability.

After Mpok Nani had left, Kinan stared at Arsen with an annoying glare then she took her phone to keep her busy. All-day long, this man had been giving her commands without asking for Kinan's opinion. Kinan knew all along how Arsen was, just like Kinan, Arsen could not be dictated as anyone's wishes. But, how stupid Kinan felt, she always followed anything that Arsen said to her. (EBM) 
Lily's obeying Ajie might be understood since he was her boss. However, the same case happened to Kinan and Arsen. He was not Kinan's boss, but she still obeyed anything that Arsen had told her; both when they were still dating and after they broke up. When Kinan replied to Arsen's question if she was seeing someone else, Arsen decided that they would go on with the matchmaking.

Kinan had double pressures; as a daughter and as a female. As a daughter, Kinan could not refuse her parents' wish. As a female, Kinan was finally subdued when Arsen did not object to the matchmaking.

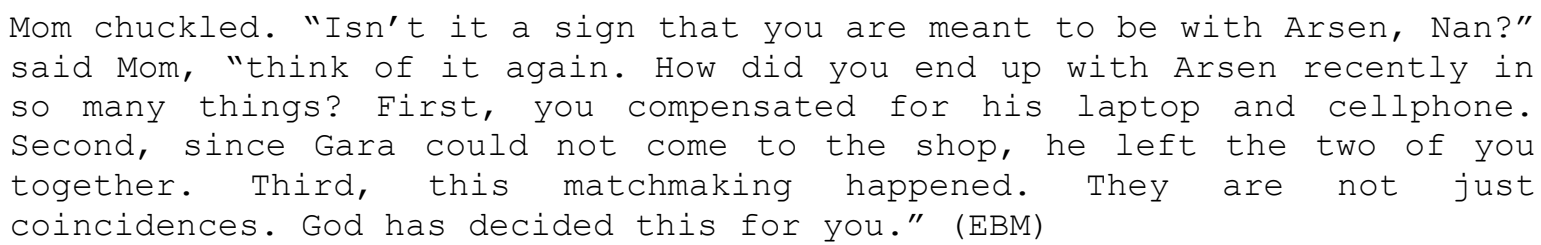

Despite her high social status, Kinan was still helpless when her parents decide everything for her marriage; from partner, wedding date, wedding organizer, to dress and ring. This helplessness leads to submissiveness and dependency; two characters that are attributed as feminine traits.

\section{Blind devotion (The “Good Woman" Syndrome)}

Another indication in the Cinderella Complex is the blind devotion demonstrated by the female characters to their male partners. Blind devotion is attributed to being "a good woman."

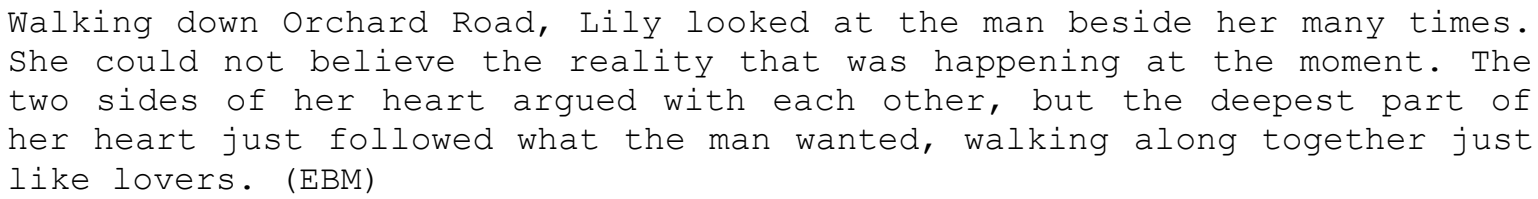

As an employee, Lily could have asked Ajie to separate between work and personal matters. However, Lily just did whatever Ajie asked her to do without questioning it further, although things that Ajie asked might not do with works or jobs. For example, when Ajie introduced Lily as his lover to Ajie's business partner, Lily played it all along, not knowing what Ajie meant.

Women have always been told repeatedly to devote themselves to their male partners (aka spouses) as one of the indications of being "good women." When Kinan called her husband "Arsen," her mother reminded Kinan that it was inappropriate.

"And also, don't call your husband by his name. It's a taboo, Nan! Impolite! You should use 'Mas' or others. Don't just call by his name," Mom advised Kinan, agreed by Mrs. Januar and Kiran. (EBM)

In Indonesia, when a wife refers to her husband, she should add another title before his name, such as "Mas," "Kang," "Pak," and others. Although the wife does not directly speak to him, she should always put the title, or simply calls him "Suamiku" (my husband) and "Bapaknya anak-anak" (the children's father). On the contrary, Arsen called Kinan by her name, both when he speaks to her directly and talks about her. However, there was no social obligation for a husband to add a title before his wife's name. 


\section{CONCLUSION}

This current study finds that both protagonists in Furious Boss \& Naughty Secretary and Ex-lovers but Married show the indications of Cinderella complex. Although the female characters differ in power and social status, they wish that someone saves them from the misery in life. Lily needed Ajie to save her from childhood trauma, while Kinan needed Arsen to prevent negative societal stigma on being labeled as a spinster. The second indication is shown through the girl-child, who still lives on the female characters. Lily was described as childish throughout the story whereas Kinan depended on others to tell her what to do, even for the most crucial part of her life: marriage. The third indication is reflected in the achievement gap. Lily claimed that she wants to be Ajie's secretary forever.

Meanwhile, unlike her single twin Kiran who expanded her business, Kinan seemed to be content with what she had achieved so far and be the wife of a billionaire. The fourth indication is the helplessness that portrays women as weak and fragile. Both Lily and Kinan were helpless when they had to face their male partners. The fifth indication is blind devotion as a sign of "good women." As Ajie's employee, Lily was entirely devoted to Ajie, even when what he ordered around crossed the line. The same thing happened to Kinan. Although Arsen was just her ex-lover at the beginning of the story, Kinan was submissive and subdued by Arsen immediately.

These findings show that working female characters in chick-lit are indicated as having the Cinderella complex, regardless of the power and social status these women may possess. They are bound to gender expectation that men are their saviors as well as their leaders. Readers seem to be aware of this pattern, but they still prefer this type of topic. The preference probably comes from their expectation to find the "Mr. Right" who happens to be "their magical prince." Thus, further study may investigate how readers-writers interactivity flourishes the indication of the Cinderella complex.

\section{REFERENCES}

Agustina, H. N. (2017). The chicklit or teenlit: A symbol of teenager's movement in Indonesia's literature. Jurnal Bahasa Lingua Scientia, 9(1). doi: dx.doi.org/10.21274/1s.2017.9.1.72-84

Contreras, D. J. A. J., Gonzaga, H. G. N., Trovela, B. M. C., \& Kagaoan, M. A. C. G. (2015). The "Wattyfever": Constructs of Wattpad readers on Wattpad's role in their lives. LPU Laguna Journal of Arts and Sciences, 2(1). Retrieved from https://lpulaguna.edu.ph/wp-content/uploads/2016/08/13.THE$\%$ E2\%80\%9CWATTYFEVER\%E2\%80\%9D-CONSTRUCTS-OF-WATTPADREADERS.pdf

Dowling, C. (1981). The Cinderella Complex: Women's Hidden Fear of Independence. New York: E-book.

Fizek, S. (2007). 'Multimodality in the context of cyberliterature-have the new electronic media revolutionized a narrative?'. On-line Proceedings of the Annual Conference of the Poetics and Linguistics Association (PALA). Retrieved from https://www.pala.ac.uk/uploads/2/5/1/0/25105678/fizek2007.pdf 
Hayles, N. K. (2008). Electronic literature: new horizons for the literary. Notre Dame: University of Notre Dame.

Hapsari A. E., Priyatama A. N., \& Kusumawati R. N. (2019). Kecenderungan cinderella complex antara wanita bekerja dan tidak bekerja ditinjau dari harga diri. Indigenous: Jurnal Ilmiah Psikologi, 4(2), 61-68. Retrieved from https://doi.org/10.23917/indigenous.v4i2.6960

Hoover, D. L., Culpeper, J., \& O'Halloran, K. (2014). Digital Literary Studies: Corpus Approaches to Poetry, Prose, and Drama. New York: Routledge.

Iinajid. (2019). Boss Galak dan Sekretaris Badung (Fierce Boos \& Naughty Secretary). Retrieved from Wattpad (www.Wattpad.com).

Intan, T. (2019). Cinderella complex dalam Eiffel I'm in Love karya Rahmania Arunita dan Fairish karya Esti Kinasih. Jentera: Jurnal Kajian Sastra, 8(2), 168-187. Retrieved from https://doi.org/10.26499/jentera.v8i2.1476

Mawardi, A. B. (2018). Komodifikasi sastra cyber Wattpad pada penerbit indie. Sabda, 13(1). Retrieved from https://ejournal.undip.ac.id/index.php/sabda/article/view/20613/13988

Merawati, F., \& Suwartini, I. (2019). The discourse of cyber literature in Indonesia. Proceeding on 2nd Workshop on Language, Literature and Society for Education. EAI. doi: 10.4108/eai.21-12-2018.2282796

Nugraha, D., \& Suyitno. (2020). The missing subject in the academic conversations on Indonesian cyberliterature. Jurnal Pendidikan Bahasa, Sastra, dan Seni, 21(1). doi: 10.24036/komposisi.v21i1.108473

Rahman, F. (2017). Cyber literature: A reader-writer interactivity. International Journal of Social Sciences \& Educational Studies, 3(4). doi:10.23918/ijsses.v3i4p156

Saha, S., \& Safri, T. S. (2016). Cinderella complex: Theoretical roots to psychological dependency syndrome in women. The International Journal of Indian Psychology, 3(3). Retrieved from http://oaji.net/articles/2016/1170-1464772133.pdf

Septriani, H. (2016). Fenomena sastra cyber: Sebuah kemajuan atau kemunduruan? (Phenomenon of cyber literature: A progress or regress?). Presented in Seminar Nasional Sosiologi Sastra di Fakultas Ilmu Pengetahuan Budaya, Universitas Indonesia.

Viires, P. (2005). Literature in cyberspace. Folklore: Electronic Jurnal of Folklore, (29), 153-174. doi: 10.7592/FEJF2005.29.cyberlit

Yoesoef, M. (2019). Cyber literature: Wattpad and Webnovel as Generation Z reading in the digital world. Proceedings of the International University Symposium on Humanities and Arts (INUSHARTS 2019. Advances in Social Science, Education and Humanities Research, 453. Retrieved from https://download.atlantispress.com/proceedings/inusharts-19/125942523 
Zakinah, N. (2020). "Ex-lovers but Married(Ex but Married)." Retrieved from Wattpad (www.Wattpad.com).

Zalbidea, M., \& Sotelo, X. (2014). Electronic literature and the effects of cyberspace on the body. CLCWeb: Comparative literature and culture, 17(5). doi.org/10.7771/1481-4374.2489 